\title{
RESEARCH ON THE HYDROLYSIS PROCESS OF SOYBEAN POWDER BY ALCALASE TO PRODUCE COMMERCIAL FERTILIZER
}

\author{
Luu Hong Son ${ }^{1}$, Dinh Thi Kim Hoa ${ }^{1}$, Nguyen Thi Tinh", \\ Nguyen Huu Tho ${ }^{1}$, Ta Thi Luong, ${ }^{1,2}$, Dang Thi Thai $\mathbf{H a}^{3^{*}}$ \\ ${ }^{1}$ TNU - University of Agriculture and Forestry, ${ }^{2}$ The University of Queensland, Australia, ${ }^{3}$ TNU - International School
}

\begin{tabular}{|c|c|c|}
\hline \multicolumn{2}{|c|}{ ARTICLE INFO } & \multirow{3}{*}{$\begin{array}{l}\text { ABSTRACT } \\
\text { The aim of the study was to investigate the single factor of the } \\
\text { appropriate mixture ratio between enzyme and EM, the ratio of } \\
\text { supplemental irrigation, incubation temperature, and hydrolysis time }\end{array}$} \\
\hline Received: & $13 / 4 / 2021$ & \\
\hline Revised: & $21 / 5 / 2021$ & \\
\hline Published: & $24 / 5 / 2021$ & affecting the hydrolysis process of soybean residues with alcalase \\
\hline & & enzyme. The dissolver protein content in hydrolysates is determined by \\
\hline \multicolumn{2}{|l|}{ KEYWORDS } & the Lowry method. The corresponding survey results were EM $2 \%+E$ \\
\hline \multicolumn{2}{|l|}{ Enzyme Alcalase } & investigating the factors affecting the hydrolysis conditions, we found \\
\hline \multicolumn{2}{|l|}{ Soybean residue } & that the mixture ratio of enzymes and EM, the ratio of supplemental \\
\hline \multicolumn{2}{|l|}{ Fertilizer } & irrigation, incubation temperature, and hydrolysis time were strongly \\
\hline \multicolumn{2}{|l|}{ Optimization } & $\begin{array}{l}\text { 1nfluencing factors to the hydrolysis process. By employing Box- } \\
\text { Behnken design, the optimal condition for the hydrolysis process of }\end{array}$ \\
\hline \multicolumn{2}{|l|}{ Box-Behnken } & $\begin{array}{l}\text { soybean residues was found, of which the mixture ratio of enzyme and } \\
\text { EM was EM } 2 \%+\mathrm{E} 1.5 \% \text {, the ratio of supplemental irrigation: } 4.2 \text {, } \\
\text { incubation temperature } 45^{\circ} \mathrm{C} \text {, hydrolysis time } 8.53 \text { hours. The } \\
\text { experimental result showed a high compatibility with the model. }\end{array}$ \\
\hline
\end{tabular}

\section{NGHIÊN CÚU QUY TRİNH THỦY PHÂN KHÔ ĐÂUU TƯƠNG BÀ̀NG CHẾ PHẨM ENZYME ALCALASE THƯƠNG MẠI ĐỂ SẢN XUẤT PHÂN BÓN DẠNG LỎNG}

\author{
Lưu Hồng Sơn ${ }^{1}$, Đinh Thị Kim Hoa ${ }^{1}$, Nguyễn Thị Tình ${ }^{1}$, \\ Nguyễn Hữu Thọ ${ }^{1}$, Tạ Thị Lượng ${ }^{1,2}$, Đặng Thị Thái Hà ${ }^{3 *}$ \\ ${ }^{1}$ Trường Đại học Nông Lâm - ĐH Thái Nguyên, ${ }^{2}$ Đại học Queensland, Úc, ${ }^{3}$ Khoa Quốc tế - ĐH Thái Nguyên
}

\begin{tabular}{|c|c|c|}
\hline \multicolumn{2}{|c|}{ THÔNG TIN BÀI BÁO } & TÓM TẮT \\
\hline Ngày nhận bài: & $13 / 4 / 2021$ & Mục đích của nghiên cứu là khảo sát đơn yếu tố tỉ lệ phối trộn thích \\
\hline Ngày hoàn thiện: & $21 / 5 / 2021$ & bồ sung, nhiệt độ ủ, thời gian thủy phân ảnh hưởng tới quá trình thủy \\
\hline Ngày đăng: & 24/5/2021 & $\begin{array}{l}\text { phân khô đậu tương bằng chế phẩm enzyme alcalase. Hàm lượng } \\
\text { protein hòa tan trong dịch thủy phân được xác định bằng phương pháp }\end{array}$ \\
\hline \multicolumn{2}{|l|}{ TÙ' KHÓA } & Lowry. Kết quả khảo sát tương ứng là: EM $2 \%+$ E $1.5 \% ; 4(\mathrm{ml} / \mathrm{g})$; \\
\hline \multicolumn{2}{|l|}{ Enzym Alcalase } & phân, chúng tôi nhận thấy tỷ lệ phối trộn giữa enzyme và EM, tỷ lệ \\
\hline \multicolumn{2}{|l|}{ Khô đậu tương } & nước bổ sung, nhiệt độ ủ, thời gian thủy phân là những yếu tố ảnh \\
\hline \multicolumn{2}{|l|}{ Phân bón } & hưởng mạnh đến quá trình thủy phân. Bằng phương pháp quy hoạch \\
\hline \multicolumn{2}{|l|}{ Tối ưu } & thực nghiệm Box- Behnken đã tìm được điều kiện tối ưu quá trình thủy \\
\hline \multicolumn{2}{|l|}{ Box-Behnken } & $\begin{array}{l}\text { E } 1.5 \% \text {, tỉ lệ nước bồ sung là: khô đậu tương: } 4.2 \text {, nhiệt độ ủ } 45^{\circ} \mathrm{C} \text {, thời } \\
\text { gian thủy phân } 8.53 \text { giờ. Kết quả thực nghiệm cho kêt quả có độ tương } \\
\text { thích cao với mô hình. }\end{array}$ \\
\hline
\end{tabular}

DOI: https://doi.org/10.34238/tnu-jst.4328

\footnotetext{
* Corresponding author. Email: dangthithaiha@gmail.com
} 


\section{Introduction}

Agricultural waste is waste produced during agricultural activities. The amount of rice waste accounts for $50 \%$ of dry matter, meaning that for every 1 ton of paddy produced, the amount of rice by-products is equivalent to 1 ton, about 10-12 tons /ha; producing 1 tonne of maize, byproducts are 1.2 tonnes of corn stalks; producing 1 hectare of peanuts emits 11 tons of peanut stalks; 1 hectare of cassava emits 7 tons of tops and fresh cassava leaves [1]. Thus, with the presently cultivated area, the estimated results of the by-products of crops of the Institute of the Agricultural Environment (2010) have shown that the whole country has about 61.43 million tonnes of by-products (including 39.9 million tons of straw, 7.99 million tonnes of rice husks, 4.45 million tons of bagasse, 1.2 million tonnes of sugar cane stalks, 4.43 million tons of corn stalks... [2]. The dry oil is the residue left after the seed oil has been pressed. Soy or soybean has the scientific name Glycine Max (L.) Merrill [3]. Soya flour is a product obtained in the form of flakes, cakes, or powder after the soya oil has been removed by extraction or pressing. Soybean powder is the insoluble portion of soy seeds with water during the production and processing of soy milk or tofu [4]. Currently, dry beans are primarily used as low-value feed. Therefore, the investigation of soybean oil liquid fertilizers by hydrolyzed enzymes for high-value crops is a promising study [5], [6]. Soya meal hydrolysis is influenced by the appropriate ratio of EM + E mix ratio, water addition ratio, incubation temperature, and hydrolysis time. Therefore, the study aims to optimize the hydrolysis of soluble proteins from soybean meal by-products at Thai Nguyen University for the production of liquid fertilizers.

\section{Material and method}

\subsection{Materials}

Materials included Soybean flour, EM preparations and hydrolysis enzymes. The soy meal was rained from the bran factory of the company Marphavet Thai Nguyen with packaging specifications for $50 \mathrm{~kg}$ bags. The materials were washed and then dried at a temperature of $80{ }^{\circ} \mathrm{C}$ up to the humidity below $10 \%$, stored in a PE bag in a sealed plastic container, stored at room temperature, protected from light and moisture. Enzyme was supplied by Novouzyme (Denmark) and EM BESTOT N02. Solvent used distilled water (pur - Vietnam) [7].

\subsection{Experiments setup}

The soluble hydrolyzed protein of soybean flour was complemented with water with the conditions in which the ratio of matter to water was 3, 4, 5; the ratio of mixture EM and enzyme was $1 \%-1.5 \% ; 1.5 \%-1.5 \% ; 2 \%-1.5 \% ; 1.5 \%-1 \% ; 1.5 \%-2 \%$; harvest temperatures were $35^{\circ} \mathrm{C}, 45^{\circ} \mathrm{C}, 55^{\circ} \mathrm{C}$ respectively; hydrolysis time was 7 hours, 8 hours, 9 hours, respectively. After conducting the single factor survey, we selected 3 most influential factors on the hydrolysis of soy flour to evaluate their effects using the surface method. An expensive indicator was used according to the experimental design of Box - Behnken with 3 elements, 3 levels.

\subsection{Determination of the soluble protein content}

The protein content dissolved in hydrolysates was determined by the Lowry method. The coprotein complex-based method reduced the mixture of phosphomolipden phosphovonphramate (Folin - ciocalteu reagent) to create a blue complex with a maximum absorption of $660 \mathrm{~nm}$. The colour intensity of the reaction mixture was proportional to protein concentration in a given range. Based on optical absorption of standard protein, the protein content of the sample could be determined.

Bovine serum albumin (BSA) was used as a standard for constructing a standard curve that shows the ratio of light absorption at $660 \mathrm{~nm}$ to protein concentration. $0.01 \mathrm{~g}(10 \mathrm{mg}$ - bovine serum albumin) was weighed and dissolved in $10 \mathrm{ml}$ of water to obtain a stock solution with a 
concentration of $1 \mathrm{mg} / \mathrm{ml}$. Then, the parent solution was diluted with distilled water at concentrations of $20,40,60,80,100,120 \mu \mathrm{g} / \mathrm{ml}$ to proceed with the construction of the standard graph. $0.5 \mathrm{ml}$ of BSA solution was taken exactly in the same dilution as before in a test tube. $2 \mathrm{ml}$ of $\mathrm{C}$ solution, which is a mixture of solution $\mathrm{A}\left(4 \mathrm{~g} \mathrm{NaOH}(0.1 \mathrm{M})\right.$ and $20 \mathrm{~g} \mathrm{Na}_{2} \mathrm{CO}_{3}$ (2\%) diluted in $1000 \mathrm{ml}$ distilled water) and solution $\mathrm{B}\left(0.5 \mathrm{~g} \mathrm{CuSO}_{4} .5 \mathrm{H}_{2} \mathrm{O}(0.5 \%)\right.$ mixed in sodium citrate solution (1\%) or $1 \%$ sodium citrate solution $1 \%$ or potassium tartrate $1 \%$ according to the ratio. 49:1) was added to each tube and left at room temperature for 10 minutes. Then, $0.25 \mathrm{ml}$ of folin reagent $(1 \mathrm{~N})$ was added and the color was compared with a wavelength of $660 \mathrm{~nm}$. Control sample: Take $0.5 \mathrm{ml}$ of distilled water in a test tube, add $2 \mathrm{ml}$ of solution $\mathrm{C}$, and the following steps are done as the experimental sample.

Through 3 repetitions of the experiment, a regression line could be built. The results were processed according to the usual statistical methods. Plot a standard graph showing the dependence of OD with protein content. Experimental sample: take exactly $0.5 \mathrm{ml}$ of protein solution with appropriate concentration into a test tube, add $2 \mathrm{ml}$ of solution $\mathrm{C}$, shake well and let stand for 10 minutes. Then add $0.25 \mathrm{ml}$ of Folin reagent diluted to 2 times in the test tube, shake well and let stand for 30 minutes, the yellow color of the mixture turns to blue and reaches the maximum color intensity. The color of the mixture was compared on a photometer at $660 \mathrm{~nm}$. The optical density (OD) value of the studied solution was determined by measuring on the machine 3 times and taking the average value. Based on the standard graph, it is possible to determine the protein content in the research sample [8], [9].

\subsection{Method of data processing}

The research data was processed by SPSS 20.0 data processing software.

\section{Results and discussions}

\subsection{Effect of the mixing ratio between EM and enzyme}

The results of the effect of mixing ratio of Alcalase enzyme and EM BESTOT N02 on the quality of water-based fertilizers are shown in Table 1.

Table 1. Results of research on the effects of the mixing relationship between EM and enzymes

\begin{tabular}{ccc}
\hline Recipes & Percentage of mixing (\%) & Soluble proteins $(\mathbf{m g} / \mathbf{m l})$ \\
\hline 1 & EM 1\% + E 1.5\% & $74.27^{\mathrm{a}}$ \\
2 & EM 1.5\% + E 1.5\% & $75.87^{b}$ \\
3 & EM 2\% + E 1.5\% & $80.55^{d}$ \\
4 & EM 1.5\% + E 1\% & $78.24^{\mathrm{c}}$ \\
5 & EM 1.5\% + E 2\% & $77.32^{\mathrm{c}}$ \\
\hline
\end{tabular}

(Note: words in the same column indicate the difference with a statistically significant difference in $\alpha=0.05$ )

Table 1 shows that the combination of enzymes and EM significantly influenced the efficiency of protein hydrolysis of soya flour as well as the soluble protein ratio of the $\mathrm{AB}$ melon plant. The combination of enzymes and EM showed significantly higher levels of soluble protein compared with the use of individual catalysts. It is easy to see that with CT3, the results were higher than the other four formulas $(80.55 \mathrm{mg} / \mathrm{ml})$. This shows that the mixing ratio of EM and enzyme preparations in CT3 (EM $2 \%+1.5 \% \mathrm{E}$ ) was most appropriate compared to other mixing formulas. In all of the comments above, we choose the $\mathrm{c} \mathrm{E}$ blend formula to fix for the next experiment.

\subsection{Effect of the proportion of added water}

Based on the results of Table 2, the quality of soya flour protein hydrolysis and the soluble protein index of melon plants changed by changing the rate of added water. The results showed that in CT2, the rate of water supplements was 4 for the highest amount of soluble proteins 
$(81.63 \mathrm{mg} / \mathrm{ml})$, much higher than CT1 and CT3. Therefore, we chose the water level that complements 4 times the volume of soy flour to do the next research

Table 2. Results of analysis of the effects of the proportion of added water

\begin{tabular}{ccc}
\hline Recipes & $\mathbf{V}_{\text {Water }}$ : Rate $\boldsymbol{m}_{\text {Soybean powder }}$ & Soluble Pro $(\mathbf{m g} / \mathbf{m l})$ \\
\hline 1 & 3 & $78.21^{\mathrm{a}}$ \\
$\mathbf{2}$ & 4 & $81.63^{\mathrm{c}}$ \\
3 & 5 & $79.22^{\mathrm{b}}$ \\
\hline
\end{tabular}

(Note: words in the same column indicate the difference with a statistically significant difference in $\alpha=0.05$ )

\subsection{Effect of the incubation temperature}

Table 3. Results of research on the effects of incubation temperature

\begin{tabular}{ccc}
\hline Recipes & ${\text { Temperature }\left({ }^{\mathbf{C}} \mathbf{C}\right)}$ & Soluble Pro $(\mathbf{m g} / \mathbf{m l})$ \\
\hline 1 & 35 & $77.33^{\mathrm{a}}$ \\
2 & 45 & $81.84^{\mathrm{c}}$ \\
3 & 55 & $81.04^{\mathrm{b}}$ \\
\hline
\end{tabular}

(Note: words in the same column indicate the difference with a statistically significant difference in $\alpha=0.05$ )

The results of research on the effects of the incubation temperature of the EM BESTOT N02 compound combined with the Alcalase enzyme on protein hydrolysis and on the growth of Japanese melon $A B$ are presented in Table 3. It can be seen that temperature affected the ability to hydrolyze proteins in short-chain proteins, amino acids, having different effects on the hydrolysis quality of soybean meal hydrolysis as well as the hydrolysis quality of soluble proteins in melon plants. Hydrolysis at $45^{\circ} \mathrm{C}$ gave the highest soluble protein content $(81.84 \mathrm{mg} / \mathrm{ml})$, higher than hydrolysis at $35^{\circ} \mathrm{C}$. However, when the temperature continued to rise to $55^{\circ} \mathrm{C}$, the efficiency of hydrolysis tended to decrease, which is due to the fact that increased temperature can cause partial denaturation of the enzyme. This result is similar to the study by Nguyen Thi Quynh Hoa [3]. From this comment, we chose the hydrolysis temperature of soybean flour for the production of water-based fertilizers at $45^{\circ} \mathrm{C}$.

\subsection{Effect of incubation time}

The results of the research on the effects of the incubation time of EM BESTOT N02 combined with the enzyme Alcalase on protein hydrolysis and growth of Japanese melon AB are presented in Table 4.

Table 4. Effect of incubation time

\begin{tabular}{ccc}
\hline Recipes & Time $(\mathbf{h})$ & Soluble Pro $(\mathbf{m g} / \mathbf{m l})$ \\
\hline 1 & $7 \mathrm{~h}$ & $78.13^{\mathrm{a}}$ \\
2 & $8 \mathrm{~h}$ & $80.91^{\mathrm{c}}$ \\
3 & $9 \mathrm{~h}$ & $80.28^{\mathrm{b}}$ \\
\hline
\end{tabular}

(Note: words in the same column indicate the difference with a statistically significant difference in $\alpha=0.05$ )

Based on the results of Table 4, by increasing incubation time, the soluble protein content obtained increased gradually from Recipe 1 to Recipe 2, Recipe 3 and reached the highest value when hydrolysed for 8 hours (Recipe 2). Thus, to save production time, choosing the time for dry soy hydrolysis by the agent was a preparation mixture EM BESTOT N02 combined with the enzyme Alcalase for 8 hours, it would give a water-based fertilizer with a protein content. The solubility was higher. 


\subsection{Optimisation of hydrolysis}

We used the method of surface criteria according to the experimental design of BoxBehnken with three variables of three levels. Data from soya flour hydrolysates treated with DesignExpert 7.0 software (Stat-Ease Inc, Minneapolis, USA) ANOVA was used to evaluate the results obtained. The optimization problem was solved using the "expected function" method. The Design-Expert 7.0 was used to perform optimization to determine the value of the three factors which had the highest soluble protein content. Using the method of regression analysis of experimental data, a quadratic polynomial model obtained, showing the soluble protein content: $\mathrm{Y}=+81.62+16.91 * \mathrm{~A}+0.59 * \mathrm{~B}+15.74 * \mathrm{C}+3.22 * \mathrm{~A} * \mathrm{~B}+12.70 * \mathrm{~A} * \mathrm{C}-4.12 * \mathrm{~B} * \mathrm{C}-21.31 * \mathrm{~A}^{2}-$ $23.57 * \mathrm{~B}^{2}-30.84 * \mathrm{C}^{2}$

When $\mathrm{Y}$ is the dissolved protein content of the hydrolyzate obtained. Values A, B, C are the values of the water-additional rate, temperature and hydrolysis time, respectively.

To find the best plan for these conditions, we chose the Box-Behnken square plan, using optimally 3 factors with 17 experiments including 5 repeated experiments in the center. The results are shown in Table 5. The results showed that the soluble protein content in the hydrolysis process was between 7.86 and $81.63 \mathrm{mg} / \mathrm{ml}$, which corresponds to experiments Nos. 9 and 17 . Based on the above results, the water ratio: soybean flour and hydrolysis time was a factor that strongly influenced the content of soluble proteins.

Table 5. Box-Behnken experimental matrix with three factors of water addition speed, temperature and hydrolysis time at soluble protein content

\begin{tabular}{|c|c|c|c|c|}
\hline \multirow[b]{2}{*}{ Experiment } & \multicolumn{3}{|c|}{ Actual variables } & \multirow[b]{2}{*}{$\begin{array}{c}\text { Dissolved pro } \\
\text { content }(\mathbf{m g} / \mathbf{m l})\end{array}$} \\
\hline & $\begin{array}{c}\text { A } \\
\text { (Additional Ratio of water) }\end{array}$ & $\begin{array}{c}\text { B } \\
\text { Temperature }\left({ }^{\circ} \mathrm{C}\right)\end{array}$ & $\begin{array}{c}\text { C } \\
\text { Hour }\end{array}$ & \\
\hline 1 & 3 & 35 & 8 & 19.55 \\
\hline 2 & 5 & 35 & 8 & 49.44 \\
\hline 3 & 3 & 55 & 8 & 17.6 \\
\hline 4 & 5 & 55 & 8 & 60.36 \\
\hline 5 & 3 & 45 & 7 & 11.31 \\
\hline 6 & 5 & 45 & 7 & 17.25 \\
\hline 7 & 3 & 45 & 9 & 16.29 \\
\hline 8 & 5 & 45 & 9 & 73.01 \\
\hline 9 & 4 & 35 & 7 & 7.86 \\
\hline 10 & 4 & 55 & 7 & 13.99 \\
\hline 11 & 4 & 35 & 9 & 48.67 \\
\hline 12 & 4 & 55 & 9 & 38.32 \\
\hline 13 & 4 & 45 & 8 & 81.62 \\
\hline 14 & 4 & 45 & 8 & 81.62 \\
\hline 15 & 4 & 45 & 8 & 81.60 \\
\hline 16 & 4 & 45 & 8 & 81.62 \\
\hline 17 & 4 & 45 & 8 & 81.63 \\
\hline
\end{tabular}

To evaluate the model, we used ANOVA analysis. ANOVA analysis results are shown in the table 6.

The results of the variance analysis of the model in Table 6 (ANOVA) also show that the water ratio and hydrolysis time significantly influenced dissolved protein content, while the hydrolysis temperature had less effect. The $F$ value of the model was 301.81 with $p<0.0001$ indicating that the selected model was meaningful. This means that the selected model was appropriate during the experiment. 
Table 6. Analysis of the ANOVA variance of the soy flour hydrolysis model

\begin{tabular}{cccccc}
\hline Source & SS & DF & MS & Standard F & Value p \\
Model & 14219.08 & 9 & 1579.90 & 301.81 & $<0.0001$ \\
A & 2288.60 & 1 & 2288.60 & 437.20 & $<0.0001$ \\
B & 2.82 & 1 & 2.82 & 0.54 & 0.4868 \\
C & 1980.72 & 1 & 1980.72 & 378.39 & $<0.0001$ \\
AB & 41.41 & 1 & 41.41 & 7.91 & 0.0260 \\
AC & 644.65 & 1 & 644.65 & 123.15 & $<0.0001$ \\
BC & 67.90 & 1 & 67.90 & 12.97 & 0.0087 \\
A $^{2}$ & 1912.74 & 1 & 1912.74 & 365.40 & $<0.0001$ \\
B $^{2}$ & 2338.89 & 1 & 2338.89 & 446.81 & $<0.0001$ \\
C $^{2}$ & 4004.98 & 1 & 4004.98 & 765.09 & $<0.0001$ \\
Residual & 36.64 & 7 & 5.23 & & \\
Lack of Fit & 36.64 & 3 & 12.21 & 81426.72 & \\
Error & $6.000 \mathrm{E}-004$ & 4 & $1.500 \mathrm{E}-004$ & & \\
SS Total & 14255.72 & 16 & & & \\
\hline
\end{tabular}

SS: Sum of variance; DF: Degree of freedom; MS: Average of variance; Standard F: Standard Fisher; Residual: The rest; "Lack of Fit": The standard assesses the incompatibility of the model with experience.

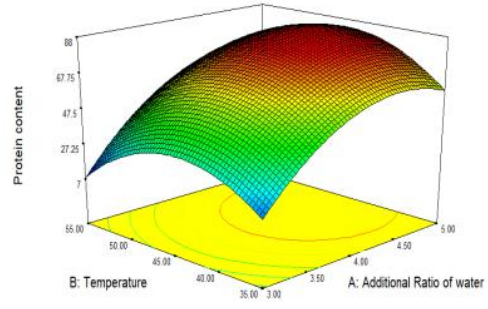

(a)

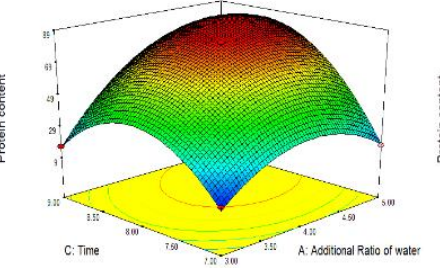

(b)

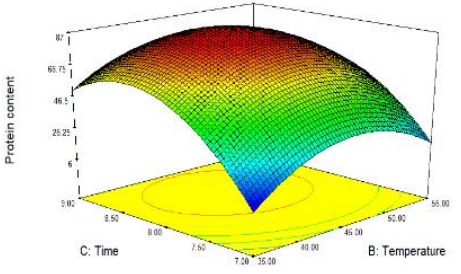

(c)

Figure 1. Superficial response to soluble protein content

a. Pattern of interaction between water-add speed and temperature

b. Model of interaction between the speed of water addition and time

c. Method of interaction between temperature and time

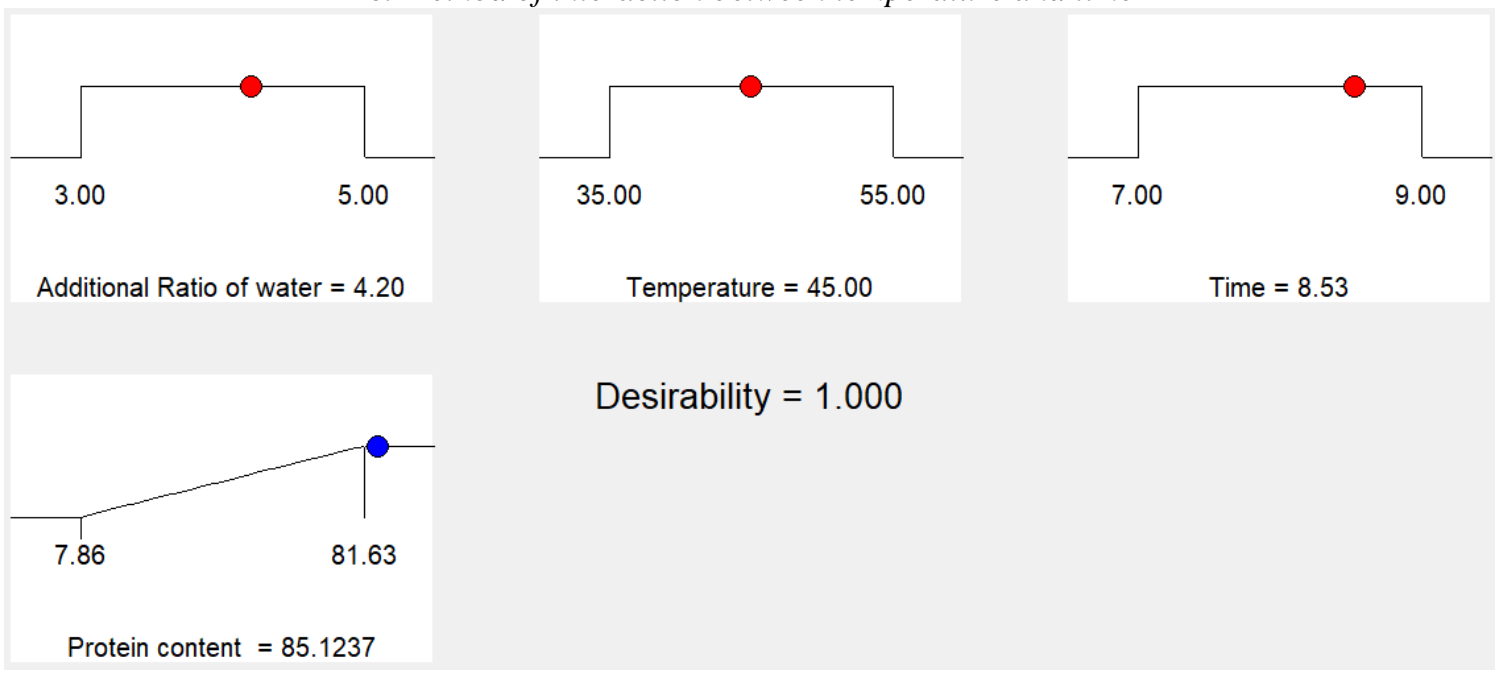

Figure 2. Expected function and optimal conditions for soluble protein content 
The "expected function" method was applied to optimize protein content obtained by the Design-Expert 7 software. The results found 43 options, where the best plan to maximize the objective function was water: material $4.2 \mathrm{ml} / \mathrm{g}$, temperature $45^{\circ} \mathrm{C}$, time 8.53 hours. The dissolved protein content obtained under the above conditions was then calculated to reach $85.1237(\mathrm{mg} / \mathrm{ml})$. This result is very compatible with the experimental results.

\section{Conclusions}

The hydrolysis conditions of soy meals suitable for obtaining soluble protein content were determined as follows: the percentage of added water was 4 , the incubation temperature was $45^{\circ} \mathrm{C}$, the incubation time with $\mathrm{EM} 2 \%+1.5 \% \mathrm{E}$ was 8 hours. We used the target surface method according to the experimental design of Box-Behnken with three variables at three levels for the best option that was planned to be the supplement rate of 4.2 , the incubation temperature was $45^{\circ} \mathrm{C}$, the time was 8.53 hours, so the soluble protein content reached $85.1237 \mathrm{mg} / \mathrm{ml}$. Our results indicate a potential use of soybean flour in the production of liquid fertilizers in agriculture.

\section{REFERENCES}

[1] H. N. Tin, Overview of Agricultural Pollution in Vietnam: Crop Industry, World Leading Group, 2017.

[2] T. C. Nguyen, Enzyme technology. Agricultural Publishing House, Ho Chi Minh City, 1998.

[3] T. Q. H. Nguyen and T. A. D. Dong, "Research on the process of hydrolysis for enteral feeding product from pork loin by Alcalase," Journal of Science - Can Tho University, vol.1 - Agriculture, pp. 140 146, 2016, doi: 10.22144/ctu.jsi.2016.032.

[4] V. D. Tran, Textbook of Soybean. Hanoi Agricultural Publishing House, 2007.

[5] V. T. Nguyen, Planting techniques of all kinds, Hanoi Agricultural Publishing House, 2016.

[6] T. K. H. Dinh, H. S. Luu, T. L. Ta, M. C. Le, D. N. Duong, V. C. Tran, D. L. Vi, T. T. Nguyen, V. D. Nguyen, and X. B. Ngo, "Optimization of the production process of liquid fertilizer from beer fermentation residue by using commercial alcalase enzyme," Scientific Journal of Tan Trao University, vol. 6, no. 17, pp. 54 - 60, 2020, doi: 10.51453/2354-1431/2020/375.

[7] V. C. Hoang, Drying technique. Science and Technology Publishing House, Hanoi, 1999.

[8] D. T. Ha, Food chemistry analysis. Science and Technology Publishing House, Hanoi, 2009.

[9] O. H. Lowry, N. J. Rosebrough, A. L. Farr, and R. J. Randall, "Protein measurement with the Folin phenol reagent," Journal of Biological Chemistry. vol. 193, pp. 265-275, 1951. 